\title{
SIMULASI PEMANFAATAN LAHAN BERDASARKAN PENDUGAAN EROSI TANAH: STUDI KASUS SUB DAS MOWEWE DI DAS KONAWEHA SULAWESI TENGGARA
}

\author{
Simulation of Land Use Based on Predicting Soil Erosion: Case Study Mowewe Sub Watershed in \\ Konaweha Watershed South East Sulawesi
}

Miranda R. Malamassam dan Sandra E. Pakasi

\begin{abstract}
Sub watershed of Mowewe has been considered as important regions in South East Sulawesi because it takes a great responsibility as a water supplier in Konaweha watershed. Konaweha watershed is a source of irrigation and domestic water for Kolaka Regency, Konawe Regency, South Konawe Regency and Kendari Municipality which have been recently in a critical condition. For this reason, it should be well managed. This study was implemented with the aim of establishing model of land use in Mowewe sub watershed that can preserve the land and water resources. The method employs a system analysis with simulation technique by using the Universal Soil Loss Equation (USLE) model based on Geographical Information Systems (GIS). The result of the research revealed that the predicting soil erosion is 68,58 ton/ha/year, more than the Tolerable Soil Loss (TSL) value of 21,52 ton/ha/year. Therefore, restructuring of land use pattern should be done to improve the condition of the area to achieve a sustainability.
\end{abstract}

Keywords : Watershed, land use, soil erosion, GIS

\section{PENDAHULUAN}

Pemanfaatan lahan di daerah hulu sungai awalnya didominasi oleh hutan, kemudian banyak dialih fungsikan untuk kegiatan lain. Hal ini terjadi akibat intervensi manusia terhadap lahan dalam rangka memenuhi kebutuhan hidupnya baik materil maupun spiritual (Arsyad, 2000). Pengalihan fungsi hutan baik untuk keperluan pertanian maupun keperluan lainnya memerlukan pemikiran secara seksama dalam pengambilan keputusan pemanfaatan yang paling menguntungkan terhadap sumberdaya lahan yang terbatas. Kecenderungan perubahan pemanfaatan lahan yang terjadi sangat potensial terhadap erosi permukaan yang akan menyebabkan degradasi lahan Asdak (2002). Demikian halnya dengan volume aliran permukaan akan meningkat seiring dengan berkurangnya penutupan lahan dan mengabaikan teknik-teknik konservasi tanah dalam pengelolaannya. Apabila tidak mendapat perhatian yang serius, maka produktifitas lahan akan terus menurun yang nantinya mempengaruhi produksi hasil pertanian. De Azevedo et al, (1999) mengemukakan bahwa pengetahuan akan keadaan spesifik suatu daerah sangat penting dalam tujuan pengelolaan pertanian lokal dan sumber daya air. Pengelolaan sumber daya tanah dan air untuk meningkatkan produksi pertanian sangat berpengaruh pada pertumbuhan dan perkembangan pembangunan suatu daerah Singh et al (1998).

Sub DAS Mowewe adalah daerah yang sangat penting, karena daerah ini bertanggung jawab sebagai penyuplai air di DAS Konaweha. DAS Konaweha yang merupakan sumber air irigasi dan air domestik Kabupaten Kolaka, Kabupaten Konawe, Kabupaten Konawe Selatan dan Kota Kendari akhir-akhir ini menunjukkan kekritisan, sehingga perlu dikelola dengan baik.

Dalam usaha pengelolaan tersebut maka penelitian ini dilaksanakan dengan tujuan membuat model pemanfaatan lahan di Sub DAS Mowewe yang didasarkan pada pengurangan laju erosi sehingga kelestarian lingkungan dapat terjaga dan masyarakat sejahtera.

\section{BAHAN DAN METODE}

\section{Tempat dan Waktu Penelitian.}

Sub DAS Mowewe merupakan bagian tengah dari DAS Konaweha. Berdasarkan wilayah administrasi daerah ini berada pada Kabupaten Kolaka dan Kabupaten Konawe, terdiri atas 25 
desa yang menyebar pada 6 kecamatan dengan luas $55.704,63$ ha. Penelitian ini dilaksanakan selama enam bulan yaitu dari Oktober 2004 sampai Maret 2005.

\section{Bahan dan Alat}

Bahan yang digunakan adalah peta geomorfologi, peta lereng, peta geologi, peta tanah, peta penggunaan lahan, peta wilayah penelitian, peta pola aliran sungai dari beberapa sumber yaitu BPN Sulawesi Tenggara tahun terakhir, BP DAS Sulawesi Tenggara, Peta Rupa Bumi dan Citra Landsat tahun 2003. Alat yang digunakan adalah seperangkat komputer dengan software GIS, GPS, kamera digital, pedoman wawancara dan pedoman observasi lapangan.

\section{Tahapan Analisis Data dan Informasi}

\section{Pembuatan Peta}

Peta dibuat secara digital dengan menggunakan beberapa software Sistem Informasi Geografis antara lain Arc-Info, Auto CAD dan Arc-View. Pada penelitian ini satuan pengamatan terkecil adalah unit lahan dan untuk informasi keseluruhan sub DAS akan diintegrasikan dari masing-masing unit lahan dengan menggunakan faktor koreksi.

(1) Pembuatan Peta Unit Lahan. Salah satu teknik untuk dapat menggambarkan unsurunsur unit lahan ke dalam satu kesatuan pemetaan adalah dengan metode tumpang tindih (overlay). Peta-peta yang digunakan untuk pembuatan peta unit lahan terdiri atas Peta Geomorfologis , Peta Kemiringan Lereng dan Peta Penggunaan Lahan.

(2) Pembuatan Peta Curah Hujan. Informasi curah hujan dan lokasi dari seluruh stasiun cuaca atau pencatat curah hujan dimasukkan dalam peta. Dengan metode Poligon Thiessen, dibuat Peta Curah Hujan tertimbang yang mewakili daerah tersebut.

(3) Peta Tanah. Informasi tanah yang diperlukan adalah data tekstur tanah, struktur tanah, permeabilitas tanah, persentase kandungan bahan organik dan ciri-ciri tanah yang berkaitan dengan erodibilitas tanah. Informasi ini dapat diperoleh dari Peta Jenis Tanah yang tersedia, atau mengambil sampel di lapangan dan dianalisis di laboratorium.

(4) Peta Kedalaman Tanah. Kedalaman tanah merupakan hal penting yang harus diketahui karena akan menentukan dalam perhitungan Tolerable Soil Loss (TSL). Informasi kedalaman tanah dapat diperoleh dari Peta Jenis Tanah atau pengukuran langsung dilapangan.

(5) Peta Status Lahan dan Fungsi Lahan. Dengan menggunakan informasi dari Pola Rehabilitasi Lahan dan Konservasi Tanah (RLKT) dan Rencana Tata Ruang Wilayah (RTRW) dibuat Peta Fungsi Lahan dan Status Lahan.

(6) Peta Pengelolaan Tanaman. Setelah peta satuan lahan di tumpang tindihkan dengan peta liputan lahan atau vegetasi/tanaman, dilakukan pengecekan lapangan, kemudian pada masing-masing satuan lahan tersebut ditambahkan notasi berupa indeks pengelolaan tanaman disebut dengan nilai "C".

(7) Peta Pengelolaan Konservasi. Seperti halnya pemetaan pengelolaan tanaman, jika memungkinkan informasi didapatkan dari interpretasi citra atau foto udara dan pengecekan langsung di lapangan. Pada masing-masing satuan lahan tersebut di tambahkan notasi berupa indeks pengelolaan konservasi tanah disebut dengan nilai "P".

\section{Perhitungan Laju Erosi}

Model pendugaan erosi dikembangkan oleh Wischmeier dan Smith (1978) yaitu Model USLE (The Universal Soil Loss Equation). Model ini telah dimodifikasi oleh Renard et al. (1992) yang dikenal dengan The Revised Universal Soil Loss Equation atau RUSLE. Penelitian ini mengunakan model RUSLE. Dugaan erosi ditentukan menurut fungsi hubungan:

\section{EROSI $=\mathbf{f}($ RKLSCP $)$}

$$
\begin{aligned}
\mathrm{R} \text { atau Erosivitas }= & \mathrm{f}(\text { Hujan }) \\
\mathrm{K} \text { atau Erodibilitas }= & \mathrm{f}(\text { Tekstur, Struktur, Bahan } \\
& \text { Organik, Permeabilitas }) \\
\mathrm{LS} \text { atau Topografi }= & \mathrm{f} \text { (Kemiringan lereng, } \\
& \text { Panjang lereng }) \\
\mathrm{C} \text { atau Tanaman }= & \mathrm{f}(\text { Jenis tanaman }) \\
\mathrm{P} \text { atau Konservasi }= & \mathrm{f}(\text { Tindakan konservasi } \\
& \text { tanah) }
\end{aligned}
$$

\section{Perhitungan TSL}

Kehilangan tanah yang dapat dibiarkan (TSL) adalah batas maksimum erosi tanah yang diperkenankan, dimana produktivitas tanah masih 
dapat dipertahankan secara ekonomis dan lestari (Wischmeier and Smith, 1978). Hamer (1991) mengenalkan konsep TSL dengan mempertimbangkan umur guna tanah yaitu waktu yang diperlukan untuk habis tererosinya suatu kedalaman tanah. Pada konsep ini, laju TSL ditentukan menurut fungsi hubungan:

$$
\mathrm{TSL}=\frac{K E^{*} F K}{U G T}
$$

di mana TSL adalah laju erosi yang masih dapat dibiarkan (mm/tahun atau ton/ha/tahun, KE adalah kedalaman efektif $(\mathrm{mm})$, FK adalah faktor kedalaman tanah dan UGT adalah umur guna tanah (untuk kepentingan pelestarian digunakan 400 tahun).

\section{Indeks Bahaya Erosi}

Informasi Indeks Bahaya Erosi dan klasifikasinya sangat diperlukan dalam menentukan daerah prioritas yang harus direhabilitasi lahannya. Indeks Bahaya Erosi ditentukan dari perhitungan nisbah antara laju erosi potensial (A) yaitu fungsi dari topografi, erodibilitas tanah dan erosivitas hujan dengan laju erosi yang masih dapat ditoleransi (TSL), atau secara persamaan matematis dapat ditulis sebagai berikut (Arsyad, 2000; Asdak, 2002):

$$
\text { Indeks Bahaya Erosi }=\frac{A(\text { ton } / \text { ha } / \text { thn })}{T S L(\text { ton } / \text { ha } / \text { thn })}
$$

Klasifikasi Indeks Bahaya Erosi menurut Hammer (1981) adalah sebagai berikut: (i) $<1.0$ adalah rendah; (ii) 1.01-4.0 adalah sedang; (iii) 4.01-10.0 adalah tinggi dan (iv) $>10.01$ adalah sangat tinggi.

\section{Alternatif Pemanfaatan Lahan}

Pada analisis ini, sejumlah skenario atau alternatif merupakan masukan model yang masing-masing akan memberikan nilai erosi yang berbeda. Alternatif terbaik adalah model pemanfaatan lahan yang dapat menurunkan laju erosi tanah. Dalam simulasi pemilihan alternatif pemanfaatan lahan digunakan metode Spreadsheet yang diaplikasikan pada Software ArcView (Amatya et al., 2002; Prahasta, 2003) agar informasi luasan dan lokasi perencanaan pemanfaatan lahan tersebut dengan mudah diakses oleh stakeholders yang membutuhkan.

\section{HASIL DAN PEMBAHASAN}

Erosi tanah yang terjadi di Sub DAS Mowewe sudah melebihi laju erosi tanah yang diperbolehkan. Laju erosi rata-rata Sub DAS Mowewe yang diekstraksi dari 607 unit lahan adalah sebesar 68,58 ton/ha/tahun sedangkan erosi yang diperbolehkan (TSL) rata-rata Sub DAS sebesar 21,52 ton/ha/tahun.

Perbandingan erosi yang terjadi pada masingmasing pemanfaatan lahan di Sub DAS Mowewe dapat dilihat pada Tabel 1.

Pemanfaatan lahan pertanian khususnya kakao, jambu mete dan kebun campuran yang didominasi oleh kakao, bukan hanya sebagai penyumbang Pendapatan Asli Daerah (PAD) tertinggi di daerah ini namun merupakan juga penyumbang erosi terbesar yaitu masing-masing 2051,86 ton/ha/thn; 1266,37 ton/ha/thn dan 1229,88 ton/ha/thn yang sudah sangat jauh melebihi erosi yang dapat dibiarkan. Perubahan pemanfaatan lahan hutan menjadi kakao dan fungsi lainnya sangat cepat terjadi di daerah ini.

Table 1. Erosion and Tolerable Soil Loss (TSL) at different land use at sub watershed Mowewe

\begin{tabular}{lrrr}
\hline \multicolumn{1}{c}{ Land use } & Area (ha) & Erosion (ton/ha/year) & TSL (ton/ha/year) \\
\hline Alang-alang & 2878,51 & 247,52 & 21,55 \\
Hutan Rawa & 151,08 & 0,35 & 21,96 \\
Hutang Lindung & 45247,28 & 13,59 & 21,60 \\
Jambu Mete & 830,21 & 1266,37 & 21,22 \\
Kakao & 59,96 & 2051,86 & 22,37 \\
Kebun Campuran & 1085,28 & 1229,88 & 21,77 \\
Pemukiman & 183,20 & 281,04 & 22,39 \\
Sagu & 167,17 & 3,91 & 22,22 \\
Sawah & 2297,01 & 6,11 & 22,29 \\
Semak Belukar & 2805,28 & 15,49 & 21,58 \\
\hline
\end{tabular}


Table 2. Soil Erosion at different land use scenario at sub watershed Mowewe

\begin{tabular}{lrrl}
\hline \multicolumn{1}{c}{ Scenario } & $\begin{array}{r}\text { Erosion } \\
\text { ton/ha/thn }\end{array}$ & $\begin{array}{r}\text { Erosion change } \\
\%\end{array}$ & \multicolumn{2}{c}{ Remarks } \\
\hline 1. Kondisi Sekarang & 68,58 & 0,00 & Dasar \\
2. Arahan /Preferensi & 62,49 & $-8,88$ & Menurunkan \\
3. Preferensi Petani & 68,12 & $-0,67$ & Menurunkan \\
4. Preferensi Petani & 77,71 & 13,31 & Meningkatkan \\
5. Preferensi Petani & 68,58 & 0,000 & Tetap \\
6. Arahan Konservasi Mekanik & 51,08 & $-25,52$ & Menurunkan \\
7. Arahan Fungsi Lahan & 108,61 & 58,37 & Meningkatkan \\
8. Kondisi ekstim & 2,90 & $-95,77$ & Menurunkan \\
9. Kondisi ekstrim & 28997,55 & 42182,81 & Meningkatkan \\
10. Arahan Konservasi Vegetatif \& Mekanik & 35,61 & $-48,08$ & Menurunkan \\
\hline
\end{tabular}

Penataan kembali model pemanfaan lahan harus segera dilakukan untuk menekan laju erosi tanah, sehingga degradasi lahan yang ada di Sub DAS Mowewe dapat berkurang. Alternatif pemanfaatan lahan diskenariokan berdasarkan nilai TSL, fungsi lahan dan nilai erosi dari setiap unit lahan yang ada di Sub DAS Mowewe. Berdasarkan tujuan dari penelitian ini yaitu mendapatkan nilai erosi yang rendah akan tetapi masyarakat juga sejahtera, maka perlu pertimbangan faktor sosial dan ekonomi dalam pembuatan skenario model pemanfaatan lahan. Tanaman yang dipilih dan teknik konservasi yang diterapkan melibatkan stakeholders yang berkepentingan dengan DAS tersebut. Dalam rangkaian penelitian ini telah dibahas model pemanfaatan lahan berdasarkan hidrologi dan model pemanfaatan lahan berdasarkan sosial dan ekonomi, pada bagian lain.

Pada penelitian ini ditetapkan sepuluh skenario untuk mendapatkan pemanfaatan lahan terbaik berdasarkan nilai $\mathrm{CN}$ aliran permukaan yang dapat diterapkan di daerah ini. Skenario tersebut sebagai berikut: (1) Pemanfaatan lahan sekarang (kondisi nyata); (2) Pemanfaatan lahan dengan meningkatkan kerapatan penutupan lahan pada kebun campuran (sesuai arahan fungsi lahan dan preferensi petani); (3) Pemanfaatan lahan dengan mengganti tanaman kakao dengan tanaman vanili (sesuai preferensi petani); (4) Pemanfaatan lahan dengan mengganti tanaman jambu mete dengan tanaman kakao (sesuai preferensi petani); (5) Pemanfaatan lahan dengan mengganti tanaman lada dengan tanaman vanili pada kebun campuran (sesuai preferensi petani); (6) Pemanfaatan lahan dengan menerapkan teknik konservasi tanah pada tanaman tahunan (sesuai arahan fungsi lahan); (7) Pemanfaatan lahan dengan mengganti semak belukar dan alang-alang yang lahannya masuk dalam fungsi kawasan budidaya pertanian dengan kebun campuran (sesuai arahan fungsi lahan); (8) Pemanfaatan lahan sebagai pembanding yaitu seluruh unit lahan dijadikan hutan (kondisi ekstrim); (9) Pemanfaatan lahan sebagai pembanding yaitu seluruh unit lahan dianggap tanpa vegetasi atau tanpa kegiatan di atasnya (kondisi ekstrim) dan (10) Pemanfaatan lahan dengan menggabungkan teknik konservasi vegetatif dan mekanik yaitu meningkatkan kerapatan penutupan lahan pada kebun campuran dan tanaman disekitar pemukiman, menghutankan semak belukar dan alang-alang (reboisasi dan penghijauan), menerapkan rorak pada tanaman tahunan serta teras gulud dan pembuatan bedeng pada tegalan (arahan konservasi tanah dan air).

Laju Erosi pada masing-masing skenario pemanfaatan lahan ditunjukkan dalam Tabel 2.

Skenario satu yaitu pemanfaatan lahan sekarang dijadikan dasar perhitungan persentase. Hasil analisis laju erosi skenario satu pada Sub DAS Mowewe diperoleh sebesar 68,58 ton/ha/thn. Skenario dua menurunkan laju erosi sebesar $8,88 \%$. Hasil ini menunjukkan, bahwa apabila terjadi perubahan pemanfaatan lahan dari penutupan lahan kurang rapat menjadi rapat akan menurunkan laju erosi. Skenario tiga yaitu mengganti tanaman kakao dengan tanaman vanili dapat menurunkan laju erosi sebesar 0,67 $\%$. Skenario empat yaitu mengganti tanaman jambu mete dengan tanaman kakao meningkatkan laju erosi sebesar 13,31\%. Skenario lima yaitu mengganti tanaman lada pada kebun campuran dengan tanaman vanili, memberikan laju erosi yang sama dengan pemanfaatan lahan sekarang. Skenario enam dengan menggunakan teknik konservasi, 
merupakan juga alternatif yang dapat digunakan pada pemanfaatan lahan di daerah ini, karena dapat menurunkan laju erosi sebesar 25,52 \%. Skenario tujuh yaitu mengganti semak belukar dan alang-alang yang lahannya masuk dalam fungsi kawasan budidaya pertanian dengan kebun campuran akan meningkatkan laju erosi sebesar $58,37 \%$. Apabila skenario ini akan diterapkan, maka pemanfaatan lahannya dapat dikombinasikan dengan menggunakan teknik konservasi lainnya seperti pada skenario enam. Alternatif pemanfaatan lahan ini dapat dipertimbangkan untuk diterapkan di daerah ini karena merubah pemanfaatan lahan tidak produktif menjadi lahan produktif, yang selanjutnya akan menambah pendapatan petani. Skenario delapan dengan menghutankan semua areal penelitian menurunkan laju erosi sebesar $95,77 \%$. Walaupun skenario ini memberikan penurunan paling maksimum dari laju erosi, namun skenario ini tidak dapat diterapkan di lapangan. Skenario sembilan yaitu seluruh unit lahan dianggap tanpa vegetasi atau tanpa kegiatan di atasnya meningkatkan laju erosi sebesar $42182,81 \%$. Skenario delapan dan skenario sembilan adalah kondisi ekstrim yang tidak dapat diterapkan di lapangan. Skenario ini dijadikan sebagai pembanding pada skenario pemanfaatan lahan lainnya. Skenario 10 yaitu pemanfaatan lahan dengan menggabungkan teknik konservasi vegetatif dan mekanik yaitu meningkatkan kerapatan penutupan lahan pada kebun campuran dan tanaman di sekitar pemukiman, menghutankan semak belukar dan alang-alang (reboisasi dan penghijauan), menerapkan rorak pada tanaman tahunan serta teras gulud dan pembuatan bedeng pada tegalan dapat menurunkan laju erosi sebesar $48,08 \%$.

Perubahan penutupan lahan rapat menjadi tidak rapat atau sama sekali tanpa vegetasi memberikan pengaruh yang jauh lebih besar terhadap laju erosi dibandingkan dengan usaha meningkatkan kerapatan penutupan lahan. Kenyataan ini harus menjadi perhatian pemerintah maupun stakeholders lainnya yang berkepentingan dengan keberlanjutan pembangunan suatu daerah.

\section{KESIMPULAN}

1. Perubahan pemanfaatan lahan dari penutupan lahan rapat menjadi kurang rapat akan meningkatkan laju erosi tanah.
2. Laju erosi tanah tergantung pada seberapa besar tingkat penurunan penutupan lahan dan teknik konservasi tanah yang diterapkan.

3. Laju erosi tanah Sub DAS Mowewe sebesar 68,58 ton/ha/tahun sudah melebihi laju erosi tanah yang diperbolehkan (TSL) yaitu sebesar 21,52 ton/ha/tahun.

4. Alternatif pemanfaatan lahan terbaik dalam menurunkan erosi tanah yaitu sebesar 48,08 $\%$ di Sub DAS Mowewe adalah pemanfaatan lahan dengan menerapkan teknik konservasi tanah.

\section{DAFTAR PUSTAKA}

Amatya, D.M., Chescheir, G.M., Skaggs, R.W., Fernandes, G.P. and Gilliam, J.W. 2002. A Watershed Analysis \& Treatment Evaluation Routine Spreadsheet (WATERS). Proceedings of the March 11-13, 2002 Confrence in Total Maximum Daily Load(TMDL) Environmental Regulations. $\mathrm{P}$ 490-495

Arsyad, S. 2000. Konservasi Tanah dan Air. IPB Press, Bogor.

Asdak, C. 2002. Hidrologi dan Pengelolaan Daerah Aliran Sungai. UGM Press, Yogyakarta.

De Avezedo, E.B., Pereira L.S. and Bernard I. 1999. Modelling The Local Climate in Islands Environments: Water Balance Aplications. Elsevier, Agricultural Water Management 40: 393-403

Hammer, W.I. 1981. Final Soil Conservation Consultant Report. Tech.Note No.26. Centre for Soil Research, Bogor.

Hammer, W.I. 1991. Second Soil Conservation Consultant Report. AGOF/INS/78/006. Tech.Note No.10. Centre for Soil Research, Bogor, Indonesia.

Prahasta, E. 2004. Sistem Informasi Geografis Tutorial ArcView. CV Informatika, Bandung.

Renard, K.G., Foster, G.R., Weesies, G.A., McCool, D.K, and Yoder, D.C.1992. Predicting Soil Erosion by Water: A Giude to Conservation Planning with the Revised Universal Soil Loss Equation (RUSLE). Soil and Water Conservation Society. U.S. Department of Agriculture. USA. 
Singh, R., Subramanian. K. and Refsgaard, J.C. Wischmeier, W.H. and Smith, D.D. 1978. 1999. Hydrological Modelling of Small Watershed Using MIKE SHE for Irrigation Planning. Elsevier, Agricultural Water Management 41: 146-166 Predicting Rainfall Erosion Losses. A Guide to Conservation Planning. USDA Agric.Handbook. No.537.

Diterima : 14 Juni 2006

\section{Miranda R Malamassam}

Lab. Teknik Penyehatan dan Lingkungan, Universitas Hasanuddin

Kampus Tamalanrea, Jl. Perintis Kemerdekaan Km. 10, Makassar 90245

Telp./Fax. 0411-587636. Indonesia

e-mail: dean_eng@intermux.web.id

\section{Sandra E. Pakasi}

Lab. Penginderaan Jarak Jauh dan SIG

Telp./Fax. 0431-846540. Indonesia

e-mail: sandrapakasi@yahoo.com 